\title{
PENGETAHUAN REMAJA TENTANG RESUSITASI JANTUNG PARU BERHUBUNGAN DENGAN EFIKASI DIRI REMAJA DI SMK NEGERI 2 SINGOSARI MALANG
}

\author{
Dudella Desnani Firman Yasin ${ }^{1)}$, Ahsan ${ }^{2)}$, Septi Dewi Rachmawati ${ }^{3)}$ \\ ${ }^{1)}$ Fakultas Ilmu Kesehatan Universitas Tribhuwana Tunggadewi \\ ${ }^{2,3)}$ Program Studi Magister Keperawatan Peminatan Gawat Darurat \\ Fakultas Kedokteran Universitas Brawijaya Malang \\ E-mail: dudellafirman@unitri.ac.id
}

\begin{abstract}
The focus of current global health problems is the death rate that occurs outside the Hospital Out-ofHospital Cardiac Arrest (OHCA) due to cardiac arrest. Every year the incidence rate is very high and increasing. Delay in reporting and providing Lung Resuscitation can result in death. Providing knowledge about CPR is expected to reduce mortality due to cardiac arrest. The purpose of this study was to determine the relationship of knowledge with adolescent self-efficacy in performing Pulmonary Resuscitation. The research design used was cross-sectional study. The research location is SMK Negeri 2 Singosari Malang. The number of respondents was 110 respondents taken by purposive sampling technique. Data analysis using chi-square test that is knowledge obtained $p=0.003(p<0.05)$. So it is very important to provide knowledge and Self-efficacy of Youth as early as possible and the school can work together with the Youth Red Cross and those who are competent in their fields to educate the CPR.
\end{abstract}

Keywords: Pulmonary Resuscitation (CPR); Teenagers; Self-Efficacy; Knowledge

\begin{abstract}
ABSTRAK
Permasalahan yang terjadi dalam kesehatan dunia saat ini adalah angka kematian yang terjadi di luar rumah sakit Out-of-Hospital Cardiac Arrest (OHCA) akibat henti jantung. Setiap tahunnya angka kejadiannya sangat tinggi dan meningkat. Keterlambatan dalam pelaporan dan pemberian tindakan Resusitasi Jantung Paru dapat mengakibatkan kematian. Dengan memberikan pengetahuan mengenai RJP diharapkan dapat mengurangi angka kematian akibat dari henti jantung. Tujuan penelitian ini adalah untuk mengetahui hubungan pengetahuan dengan efikasi diri remaja dalam melakukan Resusitasi Jantung
\end{abstract}

Cara mengutip: Yasin, D.D. Firman., Ahsan \& Ravhmawati, S. Dewi. (2020). Pengetahuan Remaja Tentang Resusitasi Jantung Paru Berhubungan dengan Efikasi Diri Remaja di SMK Negeri 2 Singosari Malang. Care:Jurnal Ilmiah Ilmu Kesehatan, 8(1), 116-126 
Paru. Desain penelitian yang digunakan adalah cross-sectional study . Lokasi penelitian di SMK Negeri 2 Singosari Malang. Jumlah responden sebanyak 110 responden yang diambil dengan teknik purposive sampling. Analisa data menggunakan uji chi-square yaitu pengetahuan didapatkan nilai $\mathrm{p}=0,003(\mathrm{p}<0,05)$. Sehingga sangat penting memberikan pengetahuan dan Efikasi Diri Remaja sedini mungkin dan pihak sekolah dapat bekerjasama dengan Palang Merah Remaja. Selain itu pada remaja perlu diberikan kajian atau sosialisasi secara teratur mengenai RJP.

Kata Kunci: Resusitasi Jantung Paru (RJP); Remaja; Efikasi Diri; Pengetahuan

\section{PENDAHULUAN}

Seseorang yang telah didiagnsa mengalami penyakit jantung atau tidak secara tiba-tiba dan mendadak mengalami henti jantung atau cardiac arrest secara tiba-tiba. Kejadian tersebut tidak bisa diperkirakan dan berlangsung sangat cepat sehingga tidak bisa diperkirkan tanda dan gejala yang muncul atau nampak (American Heart Association, 2010). Out-of-Hospital Cardiac Arrest (OHCA) menyebutkan bahwa angka kejadian henti jantung meningkat pada setiap tahunnya dimana kejadian henti jantung merupakan fokus utama permasalahan kesehatan dunia dimana angka kejadiannya sangat tinggi yaitu 50 60 per 100.000 orang per tahun (Berdowski et al., 2010). Tingginya angka kejadian OHCA juga diikuti dengan angka kelangsungan hidup penderita OHCA yang sangat kecil, yaitu $12 \%$ saja. Penyebab utama dari rendahnya survival rate korban OHCA adalah terlambatnya pelaporan dan pemberian tindakan resusitasi jantung paru (RJP) (Wnent, Grasner, Bohn et al., 2013).
Kemenkes RI pada tahun 2017 menjelaskan bahwa presentase siswa yang mengalami kejadian tidak sadarkan diri sebesar 35\%. Hal ini dikarenakan pengetahuan remaja yang rendah akan kejadian henti jantung. Solusi atas masalah tersebut adalah dengan meningkatkan peran orang awam atau bystander RJP dengan memberikan pengetahuan tentang Resusitasi Jantung Paru (RJP). Menurut AHA 2015 juga merekomendasikan dengan meningkatkan peran setiap orang untuk menjadi bystaneder RJP , setiap orang di komunitas penting diberikan pengetahuan tentang RJP karena dengan meningkatnya jumlah bystander RJP maka RJP dapat diberikan dengan cepat pada orang yang mengalami henti jantung sehingga akan meningkatkan survival rate korban OHCA sebanyak dua hingga tiga kali lipat (Hasselqvist-Ax et al., 2015). Asia Tenggara masih sedikit memiliki bystander RJP, tidak hanya di Asia tetappi di negaranegara berkembang juga memiliki jumlah 
bystander yang sedikit (Wang, Ma, \& Lu, 2015).

Seseorang yang telah mengalami henti nafas, perdarahan dan henti jantung maka perlu diberikan Resusitasi Jantung Paru. RJP sangat penting diberikan kepada masyarakat awam. Dengan meningkatnya ketrampilan mengenai RJP maka pengetahuan bystander RJP juga meningkat. Ketrampilan RJP ini dapat diberikan dan diajarkan kepada setiap orang yaitu orang remaja, orang dewasa, bahkan anak juga harus mempunyai ketrampilan ini (Frame, 2010). Siswa Sekolah Menengah Kejuruan merupakan bagian dari komunitas RJP dimana didalam sekolah terdapat siswa dengan kelompk remaja. Remaja ini merupakan kelompok anak usia sekolah dan pada tahap perkembangan ini remaja memiliki daya ingat yang kuat, ketrampilan yang tinggi dan rasa ingin tahu yang tinggi. Sehingga pada siswa SMK ini sangat penting diberikan pengetahuan tentang penanganan korban yang mengalami henti jantung serta cara penanganan yang tepat pada korban tersebut. Beberapa faktor yang menyebabkan kegagalan penanganan korban henti jantung yaitu pengetahuan yang rendah tentang RJP sehingga siswa tidak tahu cara yang tepat untuk menangani korban henti jantung.
Faktor yang mempengaruhi ketidakmauan siswa melakukan RJP salah satunya adalah kurangnya pengetahuan dalam melakukan RJP. Dengan meningkatnya pengetahuan maka akan meningkat pula jumlah bystander RJP di komunitas. Pengetahuan siswa tentang RJP perlu ditingkatkan. Tindakan RJP pada seseoang yang mengalami henti jantung harus hati-hati dengan mengetahui teknik dasar RJP. Oleh karena itu sangat penting memberikan program pelatihan RJP pada masyarakat awam sehingga dapat terjadi penuruanan terhadap korban yang mengalami henti jantung sehingga korban dapat terselamatkan oleh bystander RJP. Siswa sekolah menengah atas (SMA) akan melakukan pertolongan pada korban yang mengalami henti jantung jika siswa terebut mendapatkan pelatihan mengenai hal tersebut (Neil et al., 2011). Kurangnya pengetahuan tentang RJP merupakan faktor yang sangat penting dalam melakukan RJP. Orang awam menganggap bahwa ketika melakukan RJP maka orang awam tersebut merasa takut salah untuk melakukan RJP. Selain itu orang awam juga takut jika memberikan RJP pada korban maka si penolong akan tertular penyakitnya. Orang awam juga takut untuk memberikan pertolongan berupa ventilasi dari mulut ke mulut karena efikasi diri yang ada pada diri 
remaja masih kurang. Maka dari itu efikasi diri remaja berhubungan dalam keengganan seseorang untuk melakukan RJP terutama pada orang asing. Maka dari itu peneliti tertarik untuk mengetahui pengetahuan masyarakat orang awam yang berhubungan dengan efikasi diri remaja dalam melakukan Resusitasi Jantung Paru di SMK Negeri 2 Singosari.

\section{METODE PENELITIAN}

Penelitian ini merupakan jenis penelitian kuantitatif dengan pendekatan cross sectional. Penelitian ini dilakukan di SMK Negeri 2 Singosari, Malang. Populasi dalam penelitian ini yaitu 152 remaja di Sekolah tersebut sedangkan jumlah sampel sebanyak 110 yang diambil dengan teknik purposive sampling. Kriteria inklusi dalam penelitian ini terdiri dari (1) Siswa dengan usia 16-17 tahun; (2) Bersedia menjadi responden penelitian. Pengambilan data dilakukan selama satu kali pada bulan Juni sampai dengan Juli 2017. Untuk mengetahui gambaran dari setiap variabel yang diteliti digunakan analisis univariat. Untuk mengetahui hubungan antar variabel digunakan uji Chi-Square.

Kuesioner pengetahuan tentang tindakan RJP yang berisi pertanyaan tertutup
(Closed Ended Question) yang telah dibuat oleh kuesioner Bayu (2015). Kuesioner efikasi diri dalam melakukan tindakan RJP dikembangkan berdasarkan riset yang dilakukan oleh Howell \& Watson (2007) dan Klassen et al., (2008). Seluruh instrument tersebut telah dimodifikasi dan teruji validitas serta reliabilitasnya dan dipatkan hasil uji validitas 0,510 dan uji reabilitas dengan nilai alpha 0,739 . Berdasarkan kuesioner

\section{HASIL}

Tabel 1. Distribusi Frekuensi Karakteristik Responden

\begin{tabular}{llll}
\hline $\begin{array}{c}\text { Karakteristik } \\
\text { Responden }\end{array}$ & Jenis & f & $\mathbf{( \% )}$ \\
\hline Umur & 16 tahun & 21 & 19,1 \\
& 16 tahun & 89 & 80,9 \\
Jenis Kelamin & Laki - laki & 81 & 73,6 \\
& & & \\
& Perempuan & 29 & 26,4 \\
Pengetahuan & Tinggi & 27 & 24,5 \\
& Rendah & 83 & 75,5 \\
Efikasi Diri & Tinggi & 33 & 43,5 \\
& Rendah & 77 & 56,5 \\
Total & & 110 & 100 \\
\hline
\end{tabular}

Hasil penelitan pada Tabel 1 menunjukkan bahwa sebagian besar siswa SMK Negeri 2 yaitu berumur 17 tahun, mayoritas berjenis kelamin laki-laki dan ebagian besar mempunyai pengetahuan yang rendah dalam hal resusitasi jantung paru. 
Tabel 2. Hasil Analisis Bivariat

\begin{tabular}{llll}
\hline $\begin{array}{l}\text { Variabel Independent } \\
\text { Pengetahuan }\end{array}$ & $\begin{array}{l}\text { Variabel Dependent } \\
\text { Efikasi Diri }\end{array}$ & 0,003 & P-value \\
\hline
\end{tabular}

Tabel 2 pengetahuan dengan efikasi diri remaja didapatkan $P$-value $=0,003$ sehingga dapat disimpulkan terdapat hubungan antara pengetahuan dengan efikasi diri remaja.

\section{PEMBAHASAN}

\section{Pengetahuan Remaja}

Pengetahuan remaja tentang kejadian henti jantung masih sangat rendah. Wissenberg (2012) menjelaskan bahwa pengetahuan remaja tentang kejadian henti jantung berada ditingkat terendah yaitu $1 \%$. Angka tersebut didukung dengan data dari AHA yang menyatakan ketidakberdayaan dalam tindakan pertolongan kejadian henti jantung dimana dipengaruhi oleh pengetahuan. Masyrakat masih ragu-ragu untuk melakukan pertolongan pertama pada kejadian henti jantung dikarenakan masyarakat masih belum tau tata cara untuk melakukan pertolongan dan takut untuk melakukan tindakan tersebut. Selain itu ketakutan masyarakat untuk memberikan pertolongan kepada korban henti jantung dikarenakan akan mengakibatkan trauma yang berkelanjutan
(Nichol G，2008; Vaillancourt，2008; Zaher, 2009).

\section{Efikasi Diri Remaja}

Dalam penelitian ini didapatkan hasil bahwa efikasi diri remaja dalam melakukan RJP juga rendah. Bandura menjelaskan bahwa efikasi diri remaja terbentuk melalui sebuah proses secara kognitif sehingga dapat mempengaruhi tindakan dimana terdapat suatu tujuan tertentu. Kemampuan kognitif tersebut dapat mempengaruhi kejadian sehari-hari individu. Penelitian menyebutkan bahwa semakin efektif kemampuan individu dalam melakukan sebuah analisis dan berlatih maka akan sangat mendukung sekali tindakan individu tersebut. Sehingga individu tersebut dapat mengatasi atau mengontrol kejadian yang ada dihidupnya (Kraut, Chandler \& Hertenstein, 2016).

\section{Hubungan Pengetahuan dengan}

\section{Efikasi Diri Remaja Dalam}

\section{Melakukan Resusitasi Jantung Paru}

Hasil analisis menunjukkan bahwa nilai signifikansi yang diperoleh untuk variabel pengetahuan adalah 0,003. Oleh karena nilai signifikansi lebih kecil dari taraf 
signifikansi $5 \% \quad(p=0.003<0.05)$, maka dapat dinyatakan bahwa $\mathrm{H}_{1}$ diterima sehingga terdapat hubungan antara pengetahuan dengan efikasi diri remaja dalam melakukan resusitasi jantung paru di SMK Negeri 2 Singosari. Hasil ini sesuai dengan penelitian yang dilakukan Jenson dan Forsyth (2012) dimana pengetahuan dapat mempengaruhi efikasi diri setelah diberikan pengajaran terhadap keselamatan pada korban henti jantung efikasi diri meningkat dan hasil dari penelitian ini adalah metode yang tepat digunakan untuk meningkatkan pengetahuan yaitu dengan cara menggunakan metode pembelajaran berupa video dan mobile application. Penggunaan media ini sangat mempengaruhi pengetahuan dimana menggunakan komponen pendekatan teknologi dengan menstimulasi otak manusia. Media tersebut dapat menstimulasi otak dengan melibatkan audio, gerak video dan gambar. Efek yang didapatkan dari media ini yaitu meningkatkan kemampuan otak dengan memori jangka panjang serta dapat memudahkan seseorang untuk mengingat apa yang sudah dipelajari (Delazer et al., 2003).

Penelitian ini sejalan dengan penelitan yang dilakukan oleh Gutierrez di Filipina
(2013) dimana didapatkan hasil riset yaitu berupa pengaruh antara pengetahuan dengan efikasi diri setelah responden mendapatkan pembelajaran melalui kartu. Metode pembelajaran ini meningkatkan pengetahuan responden yang mendapatkan pembelajaran mengenai RJP sehingga efikasi diri pada responden juga meningkat. Pada penelitian ini didapatkan bahwa pemahaman konsep yang baik dapat mempengaruhi efikasi diri, dimana dengan meningkatnya pengetahuan remaja mengenai RJP maka meningkat pula efikasi diri remaja. Lynch, Einprusch, Nichol, 2005 mengungkapkan bahwa fenomena yang terjadi di masyarakat adalah kasus henti jantung merupaka kasus yang tidak dapat ditemui secara reguler dan penatalaksanaannya juga bukan merupakan tindakan yang mudah untuk dipahami dan dimengerti serta tidak mudah dilakukan ketika seseorang tersebut belum mengerti konsepnya dengan baik. Keselamatan hidup korban henti jantung sangat dipengaruhi oleh kecepatan bystander RJP dalam memberikan pertolongan. Sehingga ketika seseorang membutuhkan pertolongan dengan segera maka dibutuhkan juga kemampuan dan pengetahuan dalam melakukan RJP. Hal ini sangat penting ditekankan kepada orang awam atau bystander RJP khususnya pada remaja 
karena remaja mempunyai kemampuan motorik yang lebih. RJP ini membutuhkan pengetahuan dan kemampuan motorik karena tindakan ini merupakan tindakan yang cukup sulit dan membutuhkan suatu pelatihan. Dampak dari pengetahuan RJP yaitu dapat memberikan ketahanan memori yang cukup lama. Efikasi diri sangat dipeengaruhi oleh pengetahuan diaman pengetahuan yang cukup mengenai RJP dapat mempengaruhi efikasi diri remaja dalam melakukan RJP pada korban yang mengalami henti jantung.

Pengetahuan tentang RJP sangat dibutuhkan oleh orang awam, dimana pengetahuan ini akan mempengaruhi perilaku dalam melakukan pertolongan pada korban henti jantung. Pengetahuan tentang RJP akan meningkatkan pengetahuan orang awam mengenai tanda-tanda pasien yang harus diberikan pertolongan RJP, cara-cara melakukan RJP, serta mengetahui tanda-tanda pasien yang telah terselamatkan atau tidak terselamatkan. Pengetahuan RJP ini dapat mengurangi angka kematian pada kasus henti jantung. Tinggi rendahnya pengetahuan seseorang dapat dipengaruhi oleh berbagai macam faktor, antara lain yaitu usia, pendidikan, informasi, serta pengalaman (Notoatmodjo, 2013). Hal ini sesuai dengan penelitian yang dilakukan oleh Dariyo (2003) yang meyatakan bahwa usia remaja merupakan usia dimana individu masih bisa memecahkan masalah dengan pikiran yang abstrak. Stewart (2003) menegaskan bahwa semakin bertambahnya usia seseorang maka semakin besar pula daya tangkap dan pola pikir individu serta terdapat perkembangan yang sangat signifikan baik secara fisik, psikologis, mental dan kognitif pada remaja.

Penatalaksanaan segera pada korban yang diduga mengalami henti cjantung menggunakan Chain of Survival dimana hal ini sangat penting dilakukan untuk menyelamatkan nyawa seorang korban henti jantung. Untuk mengoptimalkan harapan hidup seseorang maka harus dilakukan sesuai dengan Chain of Survival dimana seorang harus dikenalkan terhadap pengenalan dan akses segera ke pelayanan gawat darurat segera setelah melakukan RJP dan untuk mendapatkan perawatan lebih lanjut merupakan suatu kesatuan dalam memaksimalkan harapan hidup seorang korban henti jantung. Angka keselamatan (survival rate) dapat mendekati 50\% pada kasus henti jantung apabila rantai keselamatan ini dapat dilakukan dengan efektif yang ditolong oleh relawan RJP dengan gambaran 
Ventricular fibrillation (VF). Peningkatan pengetahuan masyarakat tentang konsep Chain of Survival sangat penting dilakukan untuk mengoptimalkan penanganan korban henti jantung yang terjadi dimanapun berada (Berg, Chair, Robin et al., 2010).

Informasi yang didapatkan oleh orang awam dapat mempengaruhi seseorang melakukan tindakan karena pengaruh tersebut akan mengakibatkan perubahan perilaku pada diri individu sehingga dapat meningkatkan pengetahuan. Informasi mengenati RJP harus ditingkatkan karena semakin banyak informasi yang diterima maka akan semakin meningkat pula pengetahuan yang didapat. Hal ini juga didukung oleh penelitian yang dilakukan oleh Partiprajak dan Thongpo (2016) yang mengatakan bahwa efek langsung yang signifikan terjadi ketika orang awam atau remaja mendapatkan pelatihan tentang RJP sehingga dapat meningkatkan self efficacy pada orang awam. Selain itu ketrampilan juga sangat penting pada tindakan RJP ini.

Penelitian ini berkebalikan dengan penelitian yang dilakukan oleh Anderson, Gaetz, Masse et al (2011) di Kanada yang didapatkan hasil bahwa dalam sembilan puluh hari didapatkan perburukan secara cepat dimana pengetahuan dan ketrampilan mengenai RJP yang menggunakan metode teratur "refreshing" yang dapat dilakukan pada frekuensi tinggi, seperti setiap sembilan puluh hari (Anderson, Gaetz, \& Masse, 2011).

Hasil penelitian ini sesuai dengan penelitan Bobrow et al (2010) yang menyatakan bahwa pengetahuan mengenai telpon Emergency Medical Service (EMS) menjadi sesuatu hal yang sangat penting di masyarakat ketika terjadi kejadian henti jantung. Ketika masyarakat atau orang awam mengetahui kejadian henti jantung dan memahami bagaimana cara menolong korban henti jantung maka efikasi diri akan timbul pada saat yang tepat. Akibat dari gagalnya 'Emergency respon sesystem' pada korban henti jantung merupakan waktu yang sangat berharga untuk melakukan RJP. Pertolongan secepat dan sedini mungkin sangat berharga bagi korban yang mengalami henti jantung, hal tersbut tertuang dalam guideline pertolongan pada korban yang mengalami henti jantung. Dalam guideline ini dijelaskan bahwa orang awam yang mengetahui adanya korban tidak sadarkan diri di tempat kejadian dan orang awam tersebut mengetahui akan tanda-tanda orang yang mengalami henti jantung, maka orang tersebut meminta tolong 
orang lain untuk melakukan komunikasi terhadap sistem kegawatdaruratan yang ada. Kemudian orang awam tersbut dapat segera melakukan tindakan RJP setelah adanya komunikasi atau aktivasi dari sistem kegawatdaruratan. Sejalan dengan penelitian Suharsono dan Kartikawati (2009) yang meneliti hal yang serupa didapatkan hasil bahwa setiap individu harus mengetahui tanda awal kejadian henti jantung dimana kejadian ini sangat mengancam nyawa seseorang. Kematian mendadak dapat terjadi dalam hitungan menit jika korban yang mengalami kasus henti jantung tidak ditangani dengan segera. Penelitian serupa juga mengungkapkan bahwa penyebab gagalnya usaha menyelamatkan korban henti jantung yaitu karena orang awam tidak mampu mengenali tanda dan gejala yang terjadi pada korban yang mengalami henti jantung. Pentingnya penanganan dan pengenalan mengenai tanda dan gejala henti jantung sedini mungkin dapat menyelamatkan nyawa korban. Salah satu hal yang paling mudah dilakukan oleh masyarakat awam mengenali tanda dan gejala henti jantung yaitu dengan cara menepuk bahu korban dan dengan menayakan keadaannya (Supriyono, 2008).

\section{KESIMPULAN}

Pengetahuan remaja tentang RJP masih sangat rendah dengan jumlah remaja dengan tingkat pengetahuan rendah sebanyak 83 remaja. Efikasi diri remaja dalam melakukan RJP masih sangat kurang dibuktikan dengan 77 remaja memiliki efikasi diri yang rendah. Sehingga Pengetahuan remaja tentang RJP berhubungan dengan efikasi diri remaja dalam melakukan RJP

\section{SARAN}

Hasil penelitian ini dapat dijadikan data dasar dalam menyusun perencanaan program pembelajaran hard skill dan soft skill penatalaksanaan henti jantung dalam melaksanakan resusitasi jantung paru pada korban yang mengalami serangan jantung. Diperlukan penelitian lebih lanjut terkait hubungan proses pengambilan keputusan dengan efikasi diri remaja dalam melakukan resusitasi jantung paru. Selain itu pada remaja perlu diberikan kajian atau sosialisasi secara teratur mengenai RJP.

\section{REFERENSI}

American Heart Association CPR and First Aid. (2015). About cardiopulmonary resuscitation (CPR). Ann Intern Med. 157. p: 1928.

Anderson, G., Gaetz, M., \& Masse, J. (2011). First aid skill retention of first responders within the workplace. 
Journal of Trauma, Resuscitation ang Emergrncy Medicine.

Anderson, L. W., \& Krathwohl, D. R. (2001). A Taxonomy for learning, teaching, and assesing: A revision of Bloom's Taxonomy of Educational Objectives

Baker A,Oh Navarro E, van derHoekA. 2005. An experimental card game for teaching software engineering processes. J Syst Software 75, 3-16.

Bayu, Caroko 2015. "Pengaruh Pengetahuan Terhadap Kesediaan Resusitasi Jantung Paru" Jurnal Kesehatan, Volume 1, Nomer 1, Tahun 2015.

Berdowski J, Berg RA, Tijssen JGP, Koster RW. (2010). Global incidences of out-of-hospital cardiac arrest and survival rates: Systematic review of 67 prospective studies. Resuscitation. 81(11); 1479 - 1487

Berg, Robert A, Chair, Robin Hemphill, 2010. Part 5 : Adult Basic Life support: American Heart Association Guidlines for Cardiopulmonary Ressucitation and Emergency Cardiovascular Care. Circulation. 2010;122:S685-S705

Bobrow,B.J.2010.ChestCompressionOnlyCPRbyLayRescuersandSurvival From Out-of-Hospital Cardiac Arrest. JAMA;304(13):1447-1454

Dariyo, Agoes. (2003), Psikologi Perkembangan Dewasa Muda, Jakarta: PT Gramedia Widiasarana

Delazer, M., Yi, K., John, L., et al. (2003). Learning complex arithmetic - an fMRI study. Cognitive Brain Research 18, 76-88.

Fischer, K. W., Yan, Z., \& Stewart, J. (2003). Adult cognitive development: Dynamics in the. Canada: Sage

Frame, Sottn B. (2003). PHTLS: basic and advenced prehospital trauma life support. (5th ed). Missouri; Mosby

Gutierrez, Arnel F. 2013. Development and Effectiveness of an Educational Card Game as Supplementary Material in
Understanding Selected Topics in Biology. Education Department, Bulacan State University-Sarmiento Campus, City of San Jose del Monte, Bulacan 3023, Philippines

Hasselqvist-Ax I, Riva G, Herlitz J, et al. (2015). Early cardiopulmonary resuscitation in out-of-hospital cardiac arrest. $N$ Engl J Med;372:2307-15.

Jenson, C., \& Forsyth, DM (2012). Virtual reality simulation: using three dimentional technology to teach nursing students. Computer, Informastics, Nursing, 30 (6), 312-318.

Kanstad BK, Nilsen SA, Fredriksen K. (2011). CPR knowledge and attitude to performing bystander CPR among secondary school students in Norway. Resuscitation;82(8):1053-1059.

Kanstad SK, Nielsen SA, Fredikesen K. 2011. CPR knowledge and attitude to performing bystander CPR among secondary school students in Norway. Resuscitation 82 (2011) 10531059. Elsevier Ireland Ltd

Partiprajak, S., \& Thongpo, P. (2016). Retention of basic life support knowledge, self-effi cacy and chest compression performance in Thai undergraduate nursing students. Elsevier, 235-241. doi:10.1016/j.nepr.2015.08.012

Potts, J, \& Lynch, B. (2006). The american heart association CPR anytime program: the potential impact of highly accessible training in cardiopulmonary resuscitation. $J$ Cardiopulm, 26, 346-354.

Stewart, C. J., \& Cash, William B.. (2003). Interviu: prinsip dan praktik edisi 13. Jakarta: Penerbit Salemba Humanika.

Suharsono, T dan Kartikawati, D. 2009. Penatalaksanaan Henti jantung diluar rumah sakit. UMM Press : Malang.

Supriyono, A. D. 2008. Tanda dan Gejala Henti Jantung. Jakarta. 
Wang, J., Ma, L., \& Lu, YQ. (2015). Strategy analysis of cardiopulmonary resuscitation training in the community. Journal of Thoracic Disease, 7(7), 160-165.

Wissenberg M., Cu, t., \& Swisz. Association of national initiatives to improve cardiac arrest management with rates of bystander intervention and patient survival after out-ofhospital cardiac arrest. JAMA 2013
Oct

2;310:1377.(http://dx.doi.org/10.100 1/jama.2013.278483)

Wnent J, Grasner JT, Bohn A, Bein B, Jantzen T, Messelken M, et al. Inhospital emergency care of patients with in-hospital cardiac arrest. (2013). Anasthesiol Intensivmed Notfallmed Schmerzther;48:402-405. doi: 10.1055/s-0033-1349005. 